\title{
모두를 위한 안전한 삶(Safe Life for All): 감염병에서 자유로운 세상을 향하여
}

목차

I. 왜 감염병 대응인가?

II. 왜 특별히 개도국의 감염병 문제를 해결해야 하나?

1. 개도국의 이중부담

2. 지역적 특성

3. 사회경제적 파급력

4. 형평성

5. 취약한 보건의료체계

6. 우리의 보건 안보

III. 글로벌보건안보구상의 출범

1. 출범 배경

2. 글로벌보건안보구상의 운영 구조

NV. 우리정부의 대 개도국 GHSA 이행: 모두를 위한 안전한 삶

1. 모두를 위한 안전한 삶(Safe Life for All) 전략

2. 중점협력 목표별 추진 방안 및 평가체계

3. 모두를 위한 안전한 삶의 성과달성을 위한 제언

V. 결론

참고문헌 


\section{I. 왜 감염병 대응인가?}

2000년 UN 정상회의를 통해 국제사회가 함께 선언한 새천년개발목표(Millennium Development Goals, MDGs)는 국제보건과 감염병 역사에 커다란 전환점이 되었다. 인류가 최초로 세계의 번 영과 발전을 위해 전 UN회원국이 합의한 공동의 목표를 정립하였고 이에 따라 국제보건 기관들 은 주요 감염병 통제를 위해 적극적으로 활동 하였다. MDGs 여섯 번째 목표(MDGs 6)는 $\mathrm{HIV/AIDS}$, 말라리아 및 결핵을 주요 타겟으로 삼았고 국제기구 및 다수의 공여기관들이 감염병 의 통제를 위해 지난 15 년간 많은 투자를 하였다.

지난 MDGs 기간의 성과는 분명하다. 우선 감염병으로 인한 사망이 감소하였다. 전 세계적으 로 기생충 감염을 포함한 감염병으로 인한 사망자 수는 2000년 기준 1,210 만 명에서 2012년 기 준 950 만 명으로 감소하였다. 모든 사망원인에서 감염병이 차지하는 비율은 $23 \%$ 에서 $17 \%$ 로 감 소하였다(WHO, 2014).

MDGs 6에서 중점적으로 투자한 3개 질병 지표 또한 목표를 달성하였다. HIV/AIDS, 말라리 아 및 결핵의 발생률이 MDGs 기간 동안 감소하는데 성공하였다. 2000년과 비교할 때 새롭게 $\mathrm{HIV} / \mathrm{AIDS}$ 에 감염되는 사람의 수는 $35 \%$ 감소하였고, 말라리아는 $37 \%$, 결핵은 $18 \%$ 감소하였다 (WHO, 2015).

〈그림 1〉 2000-2015년 간 3개 질병 발생률 추세

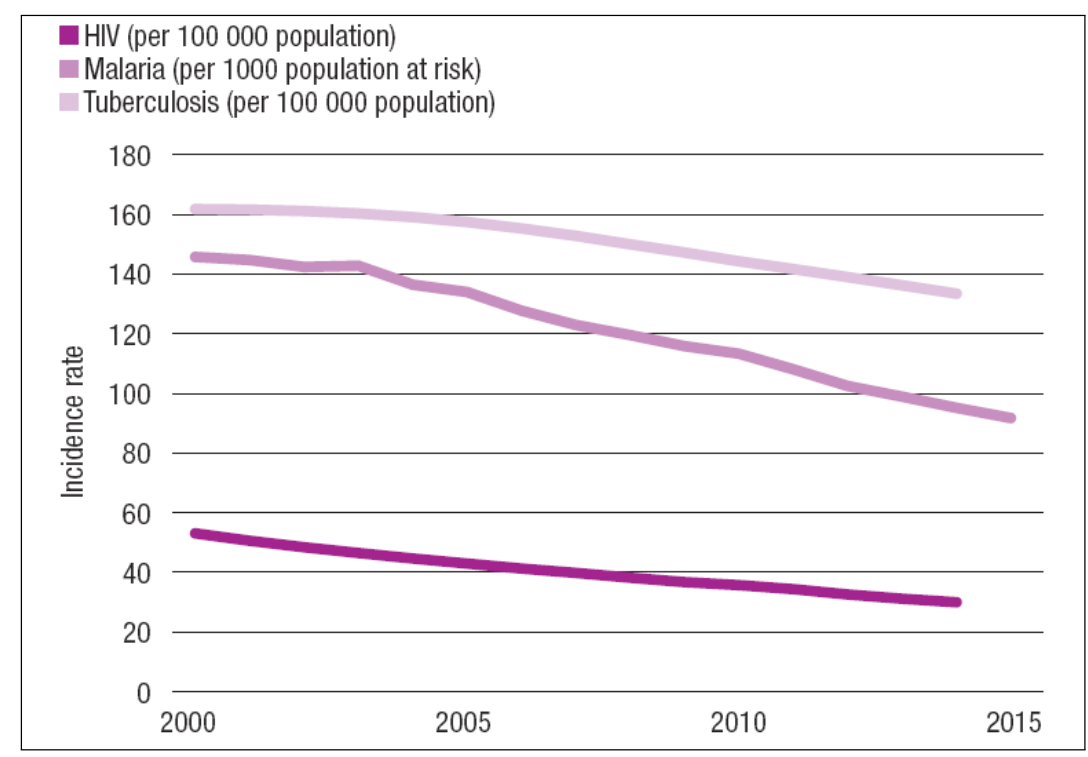

출처: $W H O$ (2015) 
이렇듯 상당한 진보를 이루어낸 MDGs의 시대를 넘어 우리는 2016년부터 2020년까지 지속가 능개발목표(Sustainable Development Goals, SDGs)의 시대를 맞이하게 되었다. SDGs 가치하 의 보건 목표는 몇몇 세부 주제에 집중하였던 $\mathrm{MDGs}$ 를 넘어 인간 삶의 모든 단계를 다루고, 보 편적 의료 보장(Universial Health Coverage, UHC)을 실현하고자 하며 보건과 다른 분야와의 연계를 추구하는 확장성과 보편성이란 특징을 보여주고 있다.

이러한 $\mathrm{SDG}$ 의 시기에 왜 우리는 감염병 대응을 강조해야하는가? 최근 가속화된 세계화에 따 라 국제사회는 인류 역사 이래로 질병전파의 가능성이 전례 없이 높아진 시대를 맞이하게 되었 다. 과거 무역과 교통이 발달하지 않은 시대에 국지적 유행으로 종료되었을만한 질병들이 이제는 짧은 시간에 전 세계에 타격을 줄 수 있는 시대가 되었다.

비록 비전염성질병이 전체 사망원인의 $68 \%$ 를 차지하는 만성질환의 시대가 도래했지만 $(\mathrm{WHO}$, 2014), 빠르게 퍼질 수 있는 감염병은 인류에게 새로운 위협을 가하고 있다. 2000년대 이후 국

제 I 장

제 II 장 제사회가 겪은 감염병의 대유행은 단순히 사망자 수를 넘어 국경통제 및 무역, 교통 등 경제성장 에 지대한 영향을 주었다.

2003년에 유행한 급성호흡기증후군(Severe Acute Respiratory Syndrome, SARS)은 8,098 명 감염과 774 명 사망자를 발생시켰고 무역과 여행에 악영향을 주었다. 2009년에 세계를 강타한 H1N1 인플루엔자 바이러스 대유행은 20만 명의 목숨을 앗아가는 결과를 낳았다(Daewood FS, 2012). 2012년에는 사우디아라비아에서 중동호흡기증후군(MERS-CoV)이 발생하여 1,112명이 감염되고 422명이 사망하였다(Mathis M, 2015). 특히 2014년부터 서아프리카에서 대유행을 한 에볼라 바이러스는 28,616 명의 감염 및 11,310 명의 사망자를 발생시켰고(WHO, 2016), 미국 및 유럽으로 감염자가 전파되어 전 세계의 공중보건 위기상황을 초래하였다.

이렇듯 우리는 SDGs와 함께 유래 없이 높아진 감염병 위협에 전 세계가 공동 대응을 해야 하 는 시대를 맞이했다. 즉 $\mathrm{SDGs}$ 가 지향하는 확장성과 보편적 의료보장의 틀 안에서 감염병 대응이 라는 주제를 풀어가야 하는 과제가 주어진 것 이다. 감염병 대응과 직접적으로 연계되는 SDGs 목표는 $3 . \mathrm{d}$ 세부 목표이다.

\section{〈상자 1〉SDGs 감염병 대응 관련 보건 목표}

\section{SDG3.d}

Strengthen the capacity of all countries, in particular developing countries, for early warning, risk reduction and management of national and global health risks

국가 및 세계적인 보건 위험에 대한 조기 경보, 위험 감축과 관리를 위해 모든 국가, 특히 개발도상국의 역량을 강화 시킨다 (번역 : 저자)

출처: UN SDG Knowledge Platform (https://sustainabledevelopment.un.org/sdg3) 


\section{II. 왜 특별히 개도국의 감염병 문제를 해결해야 하나?}

감염병 문제는 개발도상국만의 문제가 아닌 전 세계 모든 국가의 해결과제이다. 하지만 개도국 에서 감염병 대응에 특별한 노력을 우선적으로 기울여야하는 몇 가지 이유가 있다.

\section{1. 개도국의 이중부담}

현재 비전염성 질병은 개발도상국에 빠르게 확산되고 있다. 연간 3,800 만 명이 비전염성질병 으로 사망하는데 이중 3 천만 명이 저소득국과 $\mathrm{OECD}$ 가 아닌 중고소득국에 속해 있다(WHO, 2014). 개발도상국은 현재 기존에 겪고 있는 상당한 전염성 질환 부담과 함께 증가하는 비전염 성질환의 부감을 동시에 지고 있다. 이는 개도국의 보건의료체계에 이중 부담(double burden)으 로 작용하고 있다(I. C. Bygbjerg, 2012). 감염병 관리에 적절한 대응을 할 수 있는 선진국과 달리 취약한 보건의료체계를 보유한 개도국은 이러한 이중고를 시급히 해결해야하는 상황에 놓여 있다.

\section{2. 지역적 특성}

감염병은 대부분의 개도국이 속한 특정 지역에 편중되어 지속적인 부담을 주고 있다. 아프리카 의 경우 수명손실연수의 $50 \%$ 가 감염병에 기인하고 있다. 동남아시아지역 수명손실연수의 $24 \%$, 중동지역 수명손실연수의 $27 \%$ 가 감염병으로 인해 발생한다(WHO, 2015). 상대적으로 안정된 타 지역에 비해 감염병에 취약한 3 개 지역은 전 세계 감염병으로 인한 사망의 $81 \%$ 를 차지할 만큼 질병부담이 집중되어 있다. 대부분의 저소득국가가 3 개 지역에 위치하고 있으며 이러한 지정학적 특성은 감염병의 고통이 개도국 주민에게 집중되어 있다는 현실을 잘 보여주고 있다.

\section{3. 사회경제적 파급력}

기존에 진행된 연구를 통해 보건이 국가의 경제발전의 중요한 요인임은 이미 밝혀져 있다. 경 제학 연구를 통해 밝혀진 바에 의하면 보건은 개인과 인구집단 모두에서 생산성을 향상시키고 불 평등을 감소시키며 복지 및 경제성장을 촉진시킨다. 또한 삶의 질 저하를 예방하고 빈곤을 감소 시키며 국가 및 세계의 안보를 강화하는 역할을 한다(Julio Frenk, 2011). 이렇듯 사회경제적 발전의 기반을 이루는 보건이 감염병의 유행으로 인해 흔들리는 경우 이로 인한 국가 경제에 미 
치는 부정적인 효과는 매우 크다. 2014-15년 서아프리카 3개국(기니, 시에라리온, 라이베리아) 에서 발생한 에볼라 바이러스 대유행은 3개국에 치명적인 타격을 안겼다. World Bank Group은 에볼라 바이 인해 3 개국이 입은 경제적 손실은 22 억 달러에 이른다고 발표하였다(World Bank, 2016). 에볼라 바이러스 대유행 사례에서 알 수 있듯이 사회/경제적 인프라가 취약한 개발도상 국은 감염병의 유행 시 기존에 이룩했던 경제적인 성취를 쉽게 잃을 수 있는 위험을 가지고 있다.

\section{4. 형평성}

감염병 발생은 한 인구집단 내에서 임의적으로 전파되지 않는다. 감염병은 인구집단 내의 형평 성 정도에 따라 불균등하게 영향을 미친다. 가난하고 저학력이며 농촌지역에 거주하는 인구일수 록 일반적으로 더 많은 질병부담을 지게 된다(WHO, 2015). 따라서 국가적으로 사회경제적인 발 전 정도가 낮은 개발도상국의 주민들은 더 많은 질병 부담을 가지게 된다.

제 I 장

제 II 장

터

제 III 장

제 $\mathbb{N}$ 장

\section{5. 취약한 보건의료체계}

국가의 안정된 보건의료 체계 확립은 보건 안보에 있어 핵심적인 요소이다. 그간 국제사회가 겪었던 공중 보건 위기들은 만약 튼튼한 보건의료체계와 사전 대비가 선행되었다면 예방과 통제 가 가능한 사안이었다(Koivusalo, Meri, 2008). 국가의 보건의료 체계가 취약할 경우 감염병의 통제는 지극히 어렵다. 인도의 학자 Ghanshyam Shah는 인도의 수랏 지역에서 발생한 감염병 사례를 들어 사회의 보건의료 체계 조직과 감염병 대응의 중요성을 연구하였다. 해당 연구에 따 르면 수랏 지역에 전염병이 유행을 했을 당시 민간 부문에 속한 많은 수의 의사들이 제일 먼저 해당 지역을 빠져나와 타 지역으로 피신을 하였다. 전염병이 강타한 지역의 $76 \%$ 의 의료진이 피 신을 하였으며 따라서 공공 부문에 속한 의료진만이 남아서 환자를 돌보는 상황이 발생하였다 (Shah, 1997). 이 사례는 국가의 보건의료체계가 미비할 경우 얼마나 쉽게 지역 감염병 대응 체 계가 무너질 수 있는지를 보여주는 사례이다. 대부분의 개발도상국이 취약한 국가 보건의료체계 를 가지고 있는 상황을 감안할 때 개도국 보건의료 체계 강화와 연계한 감염병 대응 역량 강화 지원은 시급한 과제이다.

\section{6. 우리의 보건 안보}

국제사회는 개발도상국의 취약한 보건의료체계로 인해 국제적으로 확산된 몇몇 감염병 대유행 사례를 경험하면서 더 이상 개도국의 감염병 유행이 국지적인 문제가 아니라 선진국 경제 및 보 
건 안보에 위협을 가할 수 있는 요소임을 인지하게 되었다. SARS 발병 당시의 무역과 교통 통제 로 인한 영향, 그리고 가장 최근에 발생한 에볼라 바이러스의 국제적 전파는 특히 선진국들이 자 국의 보건안보를 위해서라도 개도국의 감염병 대응 능력을 향상시켜야 한다는 공감대를 가지게 한 사건이었다. 우리나라 또한 사우디아라비아에서 발명한 중동호흡기증후군의 국내전파를 겪으 며 해외 발생 감염병이 더 이상 타국의 문제가 아닌 우리나라를 즉각적으로 위협할 수 있다는 가 능성을 경험하였다. 개발도상국의 감염병 관리는 우리나라의 보건안보를 위해서도 반드시 지원이 필요한 영역이다.

\section{III. 글로벌보건안보구상의 출범}

\section{1. 출범 배경}

글로벌보건안보구상(Global Health Security Agenda, GHSA)은 감염병으로부터 안전한 세 계를 구축하기 위해 개별국가와 국제기구들이 구성한 국제 연합체이다. 2014년 미국의 주도로 시작되어 현재는 50개 국가와 세계보건기구(World Health Organization, WHO), 세계식량기 구(Food and Agriculture Organization, FAO), 세계동물보건기구(Organisation mondiale de la santé animale, OIE) 등 주요 국제기구들이 참여하고 있다. GHSA는 WHO의 국제보건 규칙인 'International Health Regulation 2005 (IHR 2005)'1)을 인준한 196개국 중 20\% 미 만의 국가들만이 $\operatorname{IHR}(2005)$ 의 핵심 역량 규범 기준을 따르고 있다는 문제의식에서 출범하게 되 었다(Christopher R. Braden, 2013).

GHSA는 이러한 문제를 해결하기 위해 개별국가에서 WHO에서 제정한 IHR을 이행하는 것을 촉진하여 공중 보건 비상사태 및 감염병의 위협을 관리할 수 있는 역량을 갖추게 하는 것을 목표 하고 있으며, 국제적 협력체를 구축하여 안전하게 감염병으로 부터 국제사회를 보호하는 것을 비 전으로 삼고 있다.

1) 국제보건규칙(International Health Regulation, IHR 2005)은 196개국이 서명한 가장 긴 역사와 권한을 보유한 국제보건 법으로 각 회원국의 전염병 관리 및 검염체계의 핵심 요소, 보고절차, 거버넌스 구조 등을 명시한 국제법이다. 1969년 첫 채택 이후, 2015년 까지 총 3차례 개정이 있었으며 SARS 이후 2005년 개정된 것이 최신 버전이다. 


\section{2. 글로벌보건안보구상의 운영 구조}

\section{가. 의사결정 구조}

GHSA는 선도그룹(Steering Group)이라는 의사결정 구조를 통해 의제를 이끌어 나간다. 50 개 가입국 중 2016년 현재 선도그룹은 한국, 핀란드, 인도네시아, 미국, 캐나다, 칠레, 인도, 이 탈리아, 케냐, 사우디아라비아 이며, 선도그룹 중 매년 의장국을 선발하고 있다. 핀란드, 인도네 시아는 각 각 1,2 대 의장국 직을 수행하였으며, 한국은 2017년 3대 의장국을 수행할 예정이다.

\section{나. 기술 구조}

GHSA는 감염병 통제를 예방(Prevent), 탐지(Detect), 대응(Response)의 세 가지 절차로 구 분하고 각 절차별 세부 목적 및 활동사항을 정의한 11개 행동계획(Action Packages)을 발표 하 였다.

〈표 1〉GHSA 11개 행동계획 (Action Packages)

\begin{tabular}{|c|c|}
\hline 주요 범주 & GHSA 11 Action Packages \\
\hline \multirow{4}{*}{$\begin{array}{c}\text { 예방 } \\
\text { (Prevent) }\end{array}$} & P1 항생제내성 (Antimicrobial Resistance) \\
\hline & P2 인수공통감염병 (Zoonotic Disease) \\
\hline & P3 생물안전 - 안보 (Biosafety and Biosecurity) \\
\hline & P4 예방접종 (Immunization) \\
\hline \multirow{4}{*}{$\begin{array}{c}\text { 탐지 } \\
\text { (Detect) }\end{array}$} & D1 국가 실험실 체계 (National Laboratory System) \\
\hline & D2,3 실시간 감시 (Real-Time Surveillance) \\
\hline & D4 GHSA 보고 (GHSA Reporting) \\
\hline & D5 인력양성 (Workforce Development) \\
\hline \multirow{3}{*}{$\begin{array}{c}\text { 대응 } \\
\text { (Respond) }\end{array}$} & R1 긴급대응센터 (Emergency Operations Centers) \\
\hline & $\begin{array}{c}\text { R2 보건법과 다부문 신속대응 연계 } \\
\text { (Linking Public Health with Law and Multisectoral Rapid Response) }\end{array}$ \\
\hline & $\begin{array}{l}\text { R3 의학적 대응과 인력 배치 } \\
\text { (Medical Countermeasures and Personnel Deployment Action Package) }\end{array}$ \\
\hline
\end{tabular}

출처 : 저자작성

Action Packages는 GHSA 목표 달성을 위해 실질적으로 수행해야 할 11 개 과업들의 구체적 인 정의와 목표를 제시하고 있으며 개별 행동계획별로 선도 국가와 활동 국가를 지정하여 회원국 들이 세부 과업 달성에 기여하고 실질적인 행동을 할 수 있는 구조를 갖추고 있다. GHSA 행동 
계획의 세부내용은 $\operatorname{IHR}(2005)$ 과 크게 다르지 않으나, $\operatorname{IHR}(2005)$ 을 개별국가에 적용할 수 있는 실행 구조를 갖추었다는 측면에서 의미가 있다.

한편, GHSA는 $\operatorname{IHR}(2005)$ 의 실질적 이행 도모하기 위해 WHO와 공동외부평가(Joint External Evaluation, JEE)도구를 개발하였다. JEE 도구는 $\operatorname{IHR}(2005)$ 이 제시하는 기준에 따 라 한 국가의 전염병을 예방, 탐지, 대응하는 종합적인 역량을 평가하는 도구로 개별 국가의 각 Action Package별 역량수준과 장단점을 도식화하여 제공하고 달성해야 하는 과제들을 구체적으 로 제시한다는 장점이 있다. JEE는 각 국가의 자발적 참여로 이루어지며 GHSA 회원국 및 $\mathrm{WHO}$ 에서 외부 합동 평가단을 조직하여 평가를 실시하는데 이러한 절차를 Country Assessment라 지칭한다. Country Assessment 후에는 평가결과에 따른 5개년 Country Roadmap을 수립하고 평가가 실행으로 연결될 수 있도록 하고 있다.

\section{〈그림 2〉 단계별 기술구조}

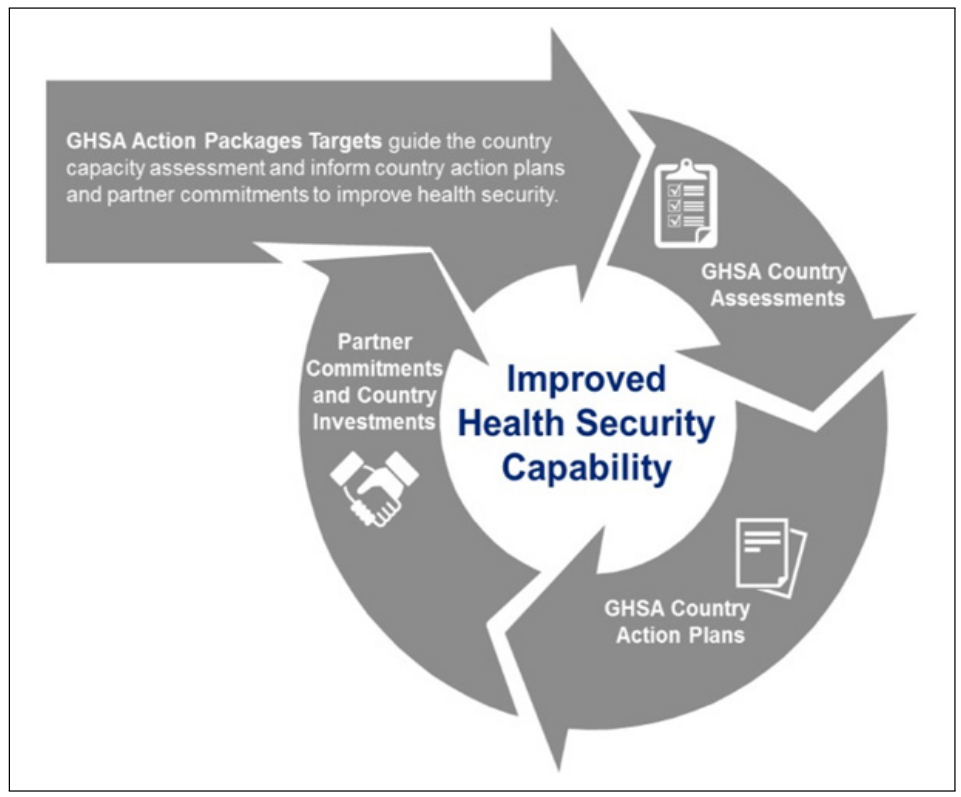

출처 : 핀란드 사회보건부 GHSA 홈페이지

GHSA는 이러한 기술적 운영 구조를 통해 국제 사회 구성원 간 원조조화 및 협력의 달성을 추구하고 있으며, 측정 가능한 목표를 제시하여 각 국가들이 GHSA 과정을 촉진하고 모니터링 하며 보고할 수 있도록 한다. 이를 통해 참여국의 자체적인 전염병 대응 역량을 증진시키는 노력 과 더불어 글로벌 협력체계를 구축하여 개발도상국의 감염병 대응 체계 강화을 위한 공여국의 참 여를 촉진하고 있다. 


\section{IV. 우리 정부의 대 개도국 GHSA 이행: 모두를 위한 안전한 삶}

\section{1. 모두를 위한 안전한 삶(Safe Life for All) 전략}

우리 정부는 GHSA 대 개도국 지원 전략으로서 2015년에 모두를 위한 안전한 삶 Safe Life

for All, SLA) 구상을 발표하였다. 동 구상을 통해 향후 5 년간 개도국에 1 억 달러를 지원하고 13 개 주요 협력국을 대상으로 11 개 Action Packages 중 3개 목표(예방접종, 국가실험실체계구 축, 보건안보인력 역량강화)를 중점적으로 지원할 계획을 공개하였다.

〈표 3〉모두를 위한 안전한 삶(SLA) 전략의 주요 협력국

\begin{tabular}{c|c|c}
\hline 구분 & 해당국가 & 비고 \\
\hline 아시아 & 캄보디아, 라오스, 우즈베키스탄 & \\
\hline 아프리카 & $\begin{array}{c}\text { 가나, 에티오피아, 시에라리온, 라이베리아, 기니, } \\
\text { DR콩고, 코트디부아르, 말리 }\end{array}$ & 에볼라 발생 3개국 포함 \\
\hline 중남미, 중동 & 요르단, 페루 & \\
\hline
\end{tabular}

출처 : 저자 작성

\section{2. 중점협력 목표별 추진 방안 및 평가체계}

'모두를 위한 안전한 삶' 구상은 모든 사람이 감염병으로 부터 안전한 삶을 살 수 있도록 지원 한다는 핵심가치를 갖고 있으며 아래와 같이 3 가지 목표별 추진 방안을 정의하고 있다.

〈그림 3〉모두를 위한 안전한 삶 구상도

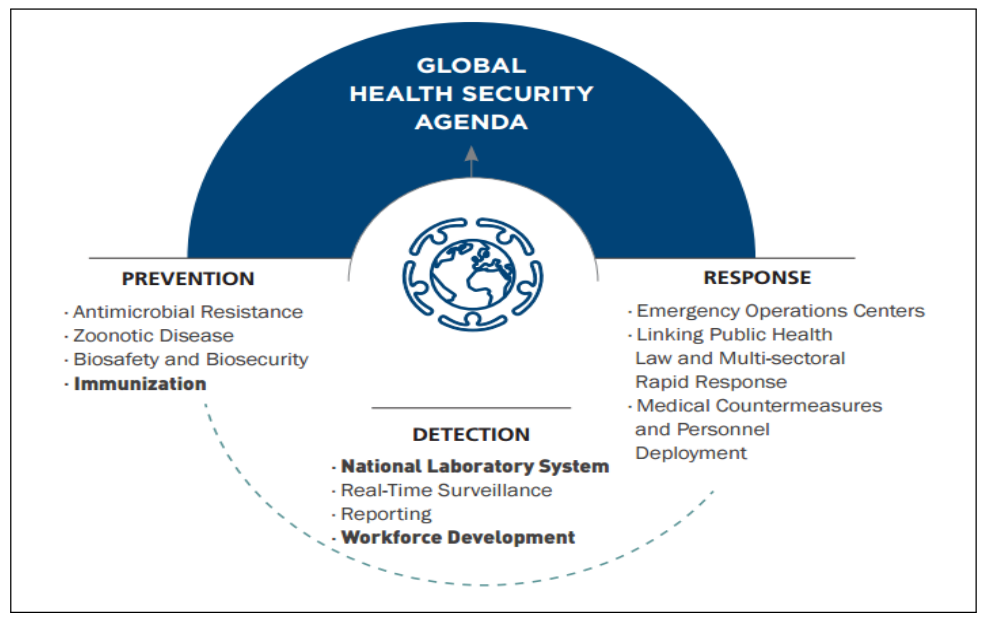

출처: KOICA (2016), 모두를 위한 안전한 삶 브로슈어 


\section{가. 예방접종}

감염병 관리에 있어 매우 비용효과적인 방법 (WHO, 2013)으로 지원의 효과성을 확보하고 GAVI, UNICEF 등 검증된 국제펀드 및 국제기구를 통해서 효과적인 지원이 가능하며, 사업 대 상국의 예방접종 관리능력 및 백신 접종률을 향상을 목표로 한다.

〈상자 2〉 예방접종 목표 주요 활동(activity) 예시

- 국가별 필수예방접종에 대한 정책적, 기술적 지원

- 백신 보급 및 보관을 위한 냉장유통 시스템을 지원

- 백신 생산을 지원

- 필수예방접종 이 외의 보조적인 예방접종 활동을 지원

- 백신으로 예방 가능한 질병들의 발생을 진단하고 조사

- 백신 및 예방접종 관련 인력을 양성

- 기타 예방접종 관리능력(질관리) 및 백신 접종률 향상을 위한 활동(취약계층 백신 접종 포함)을 지원

출처: KOICA 내부자료 (2016)

\section{나. 국가실험실체계강화}

질병의 발생 및 전파를 확인할 수 있는 질병통제의 핵심활동으로서 지원이 중요성이 높으므로 국외 유입 감염병의 관리를 위한 체계를 지원하며, 사업 대상국의 국가질병관리센터의 질병 진 단, 검사, 보고, 감시 대응 능력의 향상을 목표로 한다.

〈상자 3〉 국가실험실체계강화 목표 주요 활동(activity) 예시

- 국가, 지역, 시·군 단위의 감염병 검체 확인, 이송, 진단 역량을 평가

- 현장에서의 질병 검체의 안전한 확인 및 방역을 지원

- 검체의 신뢰할 수 있는 진단을 위하여 실험실 장비를 지원

- 신뢰도 높은 진단을 위하여 감염병 진단 인력을 역량 강화

- 검체의 안전한 이송을 위하여 검체 이송 시스템을 지원

- 질병의 진단 및 검체 이송 정보를 공유할 수 있는 시스템을 지원

출처: KOICA 내부자료 (2016)

\section{다. 보건안보인력 역량강화}

질병의 빠른 탐지와 대응 위해 개발도상국 내 감염병을 전담하여 관리할 인력 양성의 필요성 이 존재하고 우리가 국내외 질병정보를 공유하고 국제사회와 공동 대응하기 위한 인적 네트워크 구성 측면에서 중요성이 높다. 사업 대상국의 국가질병관리센터의 직원에게 감염병 관리 교육/훈 련을 제공하여 양질의 보건안보인력을 양성하는 것을 목표로 한다. 
〈상자 4〉 보건안보인력 역량강화 목표 주요 활동(activity) 예시

- 감염병에 대응하기 위한 의료진 및 역학조사관 양성을 위한 프로그램을 지원

- 각 국가별 보건의료 인력 양성을 위한 정책자문을 실시

- 각 국가별 의료진 및 역학조사관 양성을 위하여 전문가 파견을 통해 기술지원

- 양성된 보건의료 인력과 역학조사관이 적절한 활동을 할 수 있도록 감염병 예방, 진단, 대응을 위한 활동을 지원

- 국제적인 감염병 대응을 위한 네트워크 시스템을 구축

출처: KOICA 내부자료 (2016)

\section{라. 평가체계}

우리는 개별적이고 산발적인 공여국의 지원으로는 개발도상국 감염병의 예방, 탐지, 대응 역량 의 향상이 어렵다는 국제사회의 문제의식을 존중하여 원조조화를 추구할 것이다. 개별적 평가를 지양하고, GHSA와 $\mathrm{WHO}$ 가 공동 개발한 JEE 도구를 활용하여 도출된 국별 평가결과를 바탕으

로 사업 대상국 별 지원 분야 및 세부 목표를 설정하고 성과 평가에 활용할 계획이다.

\section{3. 모두를 위한 안전한 삶의 성과달성을 위한 제언}

\section{가. 벤치마킹 사례: 미국의 대 개도국 GHSA지원 ODA 운영 구조}

2016년 11월 4일 미국 정부는 버락 오바마 대통령의 행정 명령(executive order)을 통해 미 국 정부의 GHSA 목표 달성을 위한 미국 행정부의 거버넌스 구조를 조직하였다. 이 명령에는 행 정부 내 다양한 조직의 역할을 정의하고 있으며, 특별히 대 개도국 GHSA 이행을 위해서 미국 국제개발부(United States Agency for International Development, USAID)와 미국질병통제 예방센터(U.S. Center for Disease Control and Prevention, USCDC) 역할에 대해 구체적으 로 명시하고 있다.

양 기관의 공통 업무로 (1) GHSA의 확산을 위해서 현재 진행 중인 프로그램을 조정하고 수행 하는 역할 수행, (2) GHSA 목표 달성을 위해 타 정부기관과 협력하여 전략·기술에 관한 가이드 를 제공하는 역할 수행을 명시하고 있으며, 특별히 USCDC는 특별 업무로서 GHSA 외부 평가 수행 시 WHO JEE 및 IHR 집행을 포함한 다양한 방법으로 미 보건부와 협력하여 기술 자문을 제공하도록 하였다.

미국 정부는 $\mathrm{GHSA}$ 의 이행과 목표 달성을 위해 질병통제 전문기관인 $\mathrm{CDC}$ 의 기술역량을 대외 적으로 적극적으로 활용하고 있다. GHSA는 보건분야 전체를 아우르는 11 개의 Action Packages로 목표를 구성하고 있고 JEE 및 Country Assessment와 같은 전문성을 필요로 하는 
기술기준을 가지고 있으므로 원조기관의 전문성만으로는 성공적인 이행을 담보하지 못한다. 따라 서 민간, 공공분야와의 파트너십을 통해 기술지원을 확보할 때 대 개도국 감염병 분야 지원의 효 과성을 확보할 수 있을 것이다.

\section{V. 결론}

국제사회는 MDGs 이행을 통해 말라리아, HIV/AIDS, 결핵 3대 질병 지표를 성공적으로 감소 시켜왔으며 이를 발판으로 보편적 의료 보장을 담은 SDGs를 구성하고 2020 년까지 모든 세대의 건강 달성을 목표로 본격적인 출발을 하였다. 그러나 동시에 SARS, H1N1, 에볼라 등의 감염병 의 전 세계적 확산으로 국제사회는 보편적 의료보장의 구조 안에서 감염병의 문제를 해결해야 하 는 상황에 직면하였다.

특별히, 최근의 감염병 확산 추세가 보건 관리 역량이 취약한 개도국 중심으로 이루어지고 그 파급력이 해당 국가의 경제사회적 불안정성을 높일 뿐만 아니라 국제적인 안보의 영역에 대한 위 험에 까지 이르렀다. 이에 국제사회는 2014년 GHSA를 구성하고 개발도상국이 IHR(2005)의 핵 심 역량을 갖출 수 있도록 지원하기 위해 Action Packages, JEE 등과 같은 도구를 개발하였고 표준화 하는데 성공하였다. 인류의 역사와 함께 해온 전염병을 공통의 문제로 인식하고 이를 해 결하기 위해 구성된 글로벌보건안보구상은 실행 가능한 제반 도구들을 제공하고 공통으로 성과 모니터링 할 수 있는 체계를 제공한다는 측면에서 그 의미가 매우 크다.

우리 정부 또한 GHSA의 대 개도국 지원 방안으로서 '모두를 위한 안전한 삶' 구상을 발표하고 이행을 위한 구체적인 전략을 제시하였으며, 이를 통해 국제사회의 SDGs 달성과 더불어 전 세계 가 감염병으로 부터 자유로울 수 있도록 하는 목표달성 노력에 동참하고 있다. 우리 정부의 '모두 를 위한 안전한 삶의 성과를 극대화하고 광범위한 감염병 분야를 효과적으로 지원하기 위해서는 개발도상국을 이해할 수 있는 원조 전문성과 더불어 진보한 기술적 방법론을 현장에 이행할 수 있는 국내외 전문기관들과의 협력이 필요하다. 이를 위해 우리는 앞으로 SLA 개발협력 사업을 실행할 때 국제사회와의 파트너십을 우선순위에 두고 사업을 추진해야 한다. 타 공여국, 국제기 구, 국내외 감염병 전문기관과의 협력과 연대를 통해 원조조화를 이루고 원조와 감염병 전문지식 을 바탕으로 개발도상국의 공중보건위기 대응 능력을 향상을 지원해야 한다. 이럴 때에 우리 정 부의 감염병 분야 대 개도국 지원이 단기적 효과에 그치지 않고 ‘모두를 위한 안전한 삶' 이 추 구하는 질병으로부터 자유로운 세상을 실제적으로 구현할 수 있게 만들어 줄 것 이다. 


\section{〈참고문헌〉}

KOICA. 2016 “모두를 위한 안전한 삶(Safe Life for All) 사업발굴지침” (내부자료)

"Safe Life for All 브로슈어": http://www.koica.go.kr/download/2015/

2015_SDGsleaflet_kr.pdf (접속일: 2016.10.21.)

Bygbjerg, I. C., 2012. "Double Burden of Noncommunicable and Infectious Diseases in Developing Countries” Sicence Vol.337(6101): 1499-1501

Center for Disease Control and Prevention (CDC). 2015. "Decoding GHSA: U.S Centers for Disease Control and Prevention." Atlanta: CDC, available at http://www.cdc.gov/globalhealth/security/infographics/decoding_ghsa.htm （접 속일: 2016.10.21.)

Christopher R. Braden, Scott F. Dowell, Daniel B. Jernigan, and James M. Hughes. 2013. "Progress in Global Surveillance and Response Capacity 10 Years after Severe Acute Respiratory Syndrome” Emerging Infectious Diseases Vol.19(6)

Sachs J., 2001. "Macroeconomics And Health: Investing In Health For Economic Development: Report”. Geneva: WHO, available at http://apps.who.int/iris/ bitstream/10665/42435/1/924154550X.pdf (접속일: 2016.10.21.)

Daewood, F. S., Iuliano, A. D., Reed, C., Meltzer, M. I., Shay, D. K., Cheng. P. Y, et al., "Estimated global mortality associated with the first 12 months of 2009 pandemic influenza A H1N1 virus circulation: a modelling study". Lancet Infect Diseases. 2012;12(9): 687-95, available at http://www.sciencedirect.com/ science/article/pii/S1473309912701214 (접속일: 2016.10.21.)

Julio Frenk MD, PhD, Octavio Gómez-Dantés MD, MPH and Felicia M. Knaul PhD. 2011. "Globalization and Infectious Diseases". Infectious Disease Clinics of North America Vol.25(3): 593-9

Koivusalo, Meri, Mackintosh, Maureen. 2008. "Global Public Health Security: Inequality, Vulnerability and Public Health System Capabilities”. Development and Change Vol.39(6): 1163-9 
Mathis M, Briand S, Prentice T., 2015. "Emerging and re-emerging infectious threats in the 21st century". Wkly Epidemiol Rec. 2015;90(20): 238-44. Geneva: WHO

Ministry of Social Affairs and Health of Finland. "Global HEALTH Security Agenda- GHSA: Health is security," available at http://stm.fi/en/ghsagenda (접속일: 2016.10.21.)

Shah, Ghanshyam. 1997. Public health and urban development: The plague in Surat. New Delhi: SAGE publications

Simonsen L., Spreeuwenberg, P., Lustig. R., Taylor, R. J., Fleming, D. M., Kroneman, M. et al., "Global Mortality Estimates for the 2009 Influenza Pandemic from the GLaMOR Project: A Modeling Study”. PLoS Med. 2013;10(11), available at http://journals.plos.org/plosmedicine/article?id=10.1371/ journal.pmed. 1001558 (접속일: 2016.10.21.)

The White House. 2011. "Executive Order - Advancing the Global Health Security Agenda to Achieve a World Safe and Secure from Infectious Disease Threats: White House". Washington D. C.: The White House, available at https://www. whitehouse.gov/the-press-office/2016/11/04/executive-order-ad vancing-global-health-security-agenda-achieve-world（접속일: 2016.10.21.) Walker DG, Hutubessy R, Beutels P. 2009. "WHO guide for standardisation of economic evaluations of immunizations programmes". Vaccine Vol.28(11): 2356-9 WHO. 2000. "Global Health Estimates: Deaths, disability-adjusted life year (DALYs), years of life lost (YLL) and years lost due to disability(YLD) by cause, age and sex, 2000-2012". Geneva: WHO, available at http://www.who.int/ healthinfo/global_burden_disease/estimates/en (접속일: 2016.10.21.)

. 2015. "Health in 2015: from MDGs, Millennium Development Goals to SDGs, Sustainable Development Goals”. Geneva: WHO

World Bank. 2016. "World Bank Group Ebola Response Fact Sheet”. Washington D. C.: World Bank, available at http://www.worldbank.org/en/topic/health/ brief/world-bank-group-ebola-fact-sheet (접속일: 2016.10.21.)

UN SDG Knowledge Platform 홈페이지 (SDG3 소개): https://sustainabledevelopment. un.org/sdg3 (접속일: 2016.10.21.) 